\title{
Regulation by Vascular Endothelial Growth Factor of Human Colon Cancer Tumorigenesis in a Mouse Model of Experimental Liver Metastasis
}

\author{
Robert S. Warren," Hui Yuan," Mary R. Matli," Nancy A.Gillett, ${ }^{\star}$ and Napoleone Ferrara ${ }^{\star}$ \\ *Department of Surgery, University of California School of Medicine, San Francisco, California 94143; and ${ }^{\ddagger}$ the Department of \\ Cardiovascular Research, Genentech, Inc., South San Francisco, California 94080
}

\begin{abstract}
To investigate the relationship between angiogenesis and hepatic tumorigenesis, we examined the expression of vascular endothelial growth factor (VEGF) in 8 human colon carcinoma cell lines and in $\mathbf{3 0}$ human colorectal cancer liver metastases. Abundant message for VEGF was found in all tumors, localized to the malignant cells within each neoplasm. Two receptors for VEGF, KDR and fit1, were also demonstrated in most of the tumors examined. KDR and flt1 mRNA were limited to tumor endothelial cells and were more strongly expressed in the hepatic metastases than in the sinusoidal endothelium of the surrounding liver parenchyma. VEGF monoclonal antibody administration in tumor-bearing athymic mice led to a dose- and time-dependent inhibition of growth of subcutaneous xenografts and to a marked reduction in the number and size of experimental liver metastases. In hepatic metastases of VEGF antibody-treated mice, neither blood vessels nor expression of the mouse KDR homologue fik-1 could be demonstrated. These data indicate that VEGF is a commonly expressed angiogenic factor in human colorectal cancer metastases, that VEGF receptors are up-regulated as a concomitant of hepatic tumorigenesis, and that modulation of VEGF gene expression or activity may represent a potentially effective antineoplastic therapy in colorectal cancer. (J. Clin. Invest. 1995. 95:1789-1797.) Key words: KDR • Flt1 • Flk-1 • angiogenesis - hepatic
\end{abstract}

\section{Introduction}

Cancer metastasis is thought to be an inefficient process, requiring a complex set of interactions between tumor cells and the host leading to development of a grossly demonstrable secondary. A commonly described model of metastasis holds that once neoplastic cells leave a primary tumor and reach the circulation, a series of hurdles must be overcome to establish a metastatic deposit. These hurdles include evasion of host immune surveillance, arrest within a distant capillary bed, adherence to endothelial cells of the target organ, invasion across the endothelial

Address correspondence to Robert S. Warren, MD, Department of Surgery, Section of Surgical Oncology, University of California Medical Center, Room U372, San Francisco, CA 94143-0790. Phone: 415-4764089; FAX: 415-476-8696.

Received for publication 22 August 1994 and in revised form 8 December 1994.

J. Clin. Invest.

(c) The American Society for Clinical Investigation, Inc. 0021-9738/95/04/1789/09 \$2.00

Volume 95, April 1995, 1789-1797 basement membrane, proliferation of both neoplastic and stromal cells at the secondary site, and neovascularization (1). This metastatic cascade model provides a framework for the study of the regulation of metastasis and may provide insights into novel therapeutic strategies. While considerable experimental evidence lends support to the postulated roles of adhesion molecules, proteolytic enzymes, and both autocrine and paracrine growth factors in the process of metastasis (2), the contribution of angiogenesis to secondary tumor formation has principally been inferred from numerous investigations of models of subcutaneous tumor growth (3). The ability of a primary tumor to induce angiogenesis appears to reflect a balance between positive and negative regulatory factors (4) and is felt to represent a fundamental element in the control of tumor growth beyond $2-3 \mathrm{~mm}$ in greatest dimension. The majority of attention has been directed toward the identification of various peptide growth factors, elaborated by certain tumor cells, which exhibit direct angiogenic activity, as defined by their ability to stimulate proliferation and motility of endothelial cells in culture and to induce new blood vessel formation in rabbit cornea or chick chorioallantoic membrane assays (4). Recently, considerable interest has developed in the possible participation of the endothelial mitogen vascular endothelial growth factor (VEGF) ${ }^{1}$ in malignant tumor growth.

VEGF is a homodimeric glycoprotein consisting of four isoforms (containing either 121, 165, 189, or 206 amino acid residues in the mature monomer), which are generated by alternative splicing of mRNA derived from a single gene $(5,6)$. While all forms of VEGF possess a signal sequence, only the smaller two species are secreted (5). In contrast, the larger forms are associated with heparin-bound proteoglycans in the extracellular matrix (7). VEGF is mitogenic for a variety of large and small vessel endothelial cells, induces the production of tissue factor, collagenase, plasminogen activators, and their inhibitors, and stimulates hexose transport in these cells as well (for review see reference 6). VEGF is also known as vascular permeability factor by virtue of its permeability enhancing effects (8). VEGF gene expression has been demonstrated in several human cancer lines in vitro $(9)$ and in surgically resected tumors of the human gastrointestinal tract (10), ovary (11), brain (12), and kidney (13). Recently, elevated serum levels of VEGF have been reported in patients with lung and gynecologic cancers (14). Scatchard analysis of binding kinetics of ${ }^{125}$ I-VEGF to several types of bovine and human endothelial cells has indicated two classes of high affinity binding sites (15), and two receptor tyrosine kinases have recently been identified for which VEGF acts as a high affinity ligand: the fms-like tyrosine

1. Abbreviations used in this paper: $\mathrm{bFGF}$, basic fibroblast growth factor; GAPDH, glyceraldehyde phosphate dehydrogenase; HGF, hepatocyte growth factor; VEGF, vascular endothelial growth factor. 
kinase flt1 (16) and KDR (17). The importance of VEGF and its receptors in glioblastoma growth has recently been demonstrated in vivo. Kim et al. (18) reported that administration of neutralizing monoclonal antibody directed against human VEGF inhibited growth of subcutaneous human xenografts in the nude mouse, and Millauer (19) demonstrated growth suppression of the $\mathrm{C} 6$ rat glioblastoma in the nude mouse after local administration of retrovirus expressing a dominant negative mutant of flk-1, the murine homologue of KDR. In this investigation, we have examined the possible role of VEGF and its receptors in the growth of colorectal cancer metastases in the liver. While prominent tumor vascularity represents an important histologic hallmark of glioblastoma (12), colorectal cancers generally are poorly vascularized and are not characterized by prominent perivascular edema. Nevertheless, VEGF mRNA was found to be ubiquitously expressed in human liver metastases from primary colon or rectal cancers as assessed by either Northern analysis or in situ hybridization. Both flt 1 and KDR mRNA could be demonstrated in hepatic metastases but not in the surrounding normal hepatic parenchyma. We also provide evidence, using neutralizing VEGF monoclonal antibodies, that VEGF serves a major function in hepatic tumorigenesis in an athymic mouse model of experimental liver metastasis.

\section{Methods}

\section{Materials}

Guanidinium isothiocyanate was purchased from GIBCO BRL (Gaithersburg, MD). Radionucleotides were obtained from Amersham Corporation (Arlington Heights, IL). Cell culture reagents were obtained from the Cell Culture Facility, University of California Medical Center (San Francisco, CA). Recombinant human VEGF $_{165}$ (rhVEGF) was purified from conditioned media of transfected Chinese hamster ovary cells as previously described $(20,21)$. Monoclonal antibody 4.6 .1 (22) used to neutralize VEGF bioactivity in vivo as described below is specific for human VEGF.

\section{Human tissues}

Specimens of liver metastases from colorectal cancers were taken from biopsied or resected tumors after submission of the tissue to the Department of Pathology in patients with metastatic disease confined to the liver undergoing either hepatic resection or placement of an implantable infusion pump for hepatic intraarterial chemotherapy. The presence of cancer was confirmed by routine histological examination. Normal liver was obtained from those patients who underwent liver resection for colorectal cancer metastases and was taken from a portion of the specimen well away from all surgical margins. Aliquots of tissue were either frozen immediately in liquid nitrogen or prepared for in situ hybridization by fixation in $4 \%$ paraformaldehyde at $4^{\circ} \mathrm{C}$ for $4 \mathrm{~h}$, followed by immersion in $15 \%$ sucrose/PBS at $4^{\circ} \mathrm{C}$ for $2 \mathrm{~h}$, and then embedded in optimal cutting temperature compound. All specimens were stored at $-70^{\circ} \mathrm{C}$.

\section{In situ hybridization for VEGF, ftt $1, f l k-1$, and $K D R$}

Antisense and sense riboprobes for VEGF were obtained by subcloning a fragment corresponding to the residues 924-1920 of a human cDNA (5) into a pRK5 vector in both orientations with respect to the SP6 promoter. The linearized riboprobes were labeled with $125 \mu \mathrm{Ci}\left[{ }^{33} \mathrm{P}\right] \mathrm{UTP}$ ( $>2,000 \mathrm{Ci} / \mathrm{mmol}$; DuPont-New England Nuclear, Boston, MA) in an in vitro transcription reaction.

For the VEGF receptors KDR, flt1 and flk-1, PCR was used to derive a template for subsequent in vitro transcription as previously described (23). For KDR, PCR primers were designed to generate a fragment that spanned the transmembrane region, corresponding to nucleotides 2098-2408 of the cDNA sequence. For flt, primers for PCR were designed to include the transmembrane domain, generating a fragment corresponding to nucleotides 2088-2475 of the full length cDNA clone. Sequences for T3 and T7 bacteriophage promoter were included in the original PCR primer sequence for both templates. Each template was then used to generate ${ }^{33} \mathrm{P}$-labeled antisense and sense RNA probes by in vitro transcription. For hybridization, 5-mm sections were prepared and treated as previously described (18).

\section{Cell lines and culture}

The human colorectal carcinoma lines LS174T, HCT 15, SW 620, COLO 201, COLO 205, and COLO 320 (obtained from Dr. Young Kim, UCSF) were grown and maintained in DMEM supplemented with $10 \%$ fetal bovine serum, penicillin $(100 \mathrm{U} / \mathrm{ml})$ and streptomycin $(100$ $\mu \mathrm{g} / \mathrm{ml}$ ) (complete DMEM), in a $5 \% \mathrm{CO}_{2}$ environment unless otherwise indicated. LS LiM 6 is a derivative of LS 174T selected for its high liver metastasizing ability during cecal growth (24), and HM7 is a variant of LS 174T selected in vitro for high mucin production which also has a high liver-colonizing capacity after splenic-portal injection in athymic mice (25). To determine the effect of rhVEGF on proliferation of colon carcinoma lines in vitro, 2,000 cells/well were cultured overnight in flat-bottom 96 -well microtiter plates at $37^{\circ} \mathrm{C}$ in complete DMEM. The medium was aspirated and fresh serum-free medium containing $0-100 \mathrm{ng} / \mathrm{ml} \mathrm{rhVEGF}$ or $10 \mu \mathrm{g} / \mathrm{ml}$ of $\mathrm{mAb} 4.6 .1$ was added to 5 replicate wells. Cells were cultured for $72 \mathrm{~h}$, and cell number was estimated using the MTT assay (26). For determination of VEGF secretion, the cell lines COLO 205, HCT 15, and LS LiM6 were grown to confluence in 6-well tissue culture plates in complete DMEM. The cultures were washed with HBSS and replaced with $2.0 \mathrm{ml}$ of fresh serum-free medium. Cells were maintained at $37^{\circ} \mathrm{C}$ for $48 \mathrm{~h}$, conditioned media were collected, cells were removed by centrifugation at 10,000 $\mathrm{rpm}$ for $10 \mathrm{~min}$, and supernatants were stored at $-70^{\circ} \mathrm{C}$. VEGF immunoactivity was assayed in duplicate cultures by ELISA as previously described (21).

\section{Cell migration assay}

The effect of anti-VEGF on migration of colon carcinoma lines was demonstrated by using the microcarrier bead assay (27). Briefly, a suspension of LS LiM6 cells was seeded into a 100-mm culture dish at $10^{5}$ cells $/ \mathrm{ml}$ in $20 \mathrm{ml}$ of complete DMEM and $5 \mathrm{mg} / \mathrm{ml}$ dextran matrix beads (Cytodex 2; Pharmacia LKB Biotechnology, Piscataway, NJ). Bead cultures were incubated for $3 \mathrm{~d}$, allowing cells to attach to beads and undergo 1-2 doublings. Attached cells were counted by removing a 1-ml aliquot from the bead culture, washed with $\mathrm{Ca}^{2+} \mathrm{Mg}^{2+}$-free phosphate-buffered saline, trypsinized ( $0.05 \%$ trypsin/0.02\% EDTA in $\mathrm{Ca}^{2+} /$ $\mathrm{Mg}^{2+}$-free HBSS) to detach cells, and counted with hemacytometer. The bead suspension was adjusted to $2 \times 10^{5} \mathrm{cells} / \mathrm{ml}$ in serum-free DMEM, and $0.5 \mathrm{ml}$ was seeded into $2-\mathrm{cm}^{2}$ wells of 24-well plates. To each of six wells, $50 \mu \mathrm{g} / \mathrm{ml}$ rhVEGF or epidermal growth factor (Sigma Chemical Co., St. Louis, MO), and $10 \mu \mathrm{g} / \mathrm{ml}$ anti-VEGF mAb 4.6.1 or control $\mathrm{mAb}$ was added in a volume of $25 \mathrm{ml}$ in various combinations as shown in Table I. Plates were incubated for $48 \mathrm{~h}$, after which the wells were rinsed three times with PBS to remove beads, and the attached cells were stained with $1.0 \%$ crystal violet in deionized water. The cells were counted by optical microscopy using a Zeiss ID 02 microscope and $\times 10$ objective. Data were expressed as cells per 10 fields.

\section{RNA isolation and Northern analysis}

All colon carcinoma lines were grown to confluence in complete DMEM in 2-cm tissue culture plates, and total cellular RNA was extracted using RNAzol B (Tel-Test, Inc.; Friendswood, TX). Total RNA from human tissues was prepared using the guanidinium isothiocyanate/cesium chloride gradient method (28). RNA samples were resolved by electrophoresis through $1 \%$ agarose gels containing $2.2 \mathrm{M}$ formaldehyde in Pipes buffer, transferred to nylon membranes (Amersham Corp.), and crosslinked to the membranes by ultraviolet irradiation. Blots were hybridized to the full length fragment of human $\mathrm{VEGF}_{165} \mathrm{cDNA}$ for $1 \mathrm{~h}$ at $68^{\circ} \mathrm{C}$ in QuikHyb (Stratagene, La Jolla, CA). The cDNA probes were labeled with $\left[\alpha^{-32} \mathrm{P}\right] \mathrm{dCTP}$ to a specific activity of $1-2 \times 10^{8} \mathrm{cpm} / \mathrm{mg}$ DNA using 
Table I. Effect of VEGF on Migration of the Human Colon Carcinoma LSLiM6 In Vitro*

\begin{tabular}{llc}
\hline \multicolumn{1}{c}{ Condition } & \multicolumn{1}{c}{ Concentration } & Cell migration $^{\ddagger}$ \\
\hline & & $\begin{array}{c}\text { (cells per 10 high } \\
\text { power fields) }\end{array}$ \\
Control & - & $186 \pm 11$ \\
rhVEGF ${ }_{165}$ & $50 \mathrm{ng} / \mathrm{ml}$ & $255 \pm 31$ \\
VEGF mAb & $10 \mu \mathrm{g} / \mathrm{ml}$ & $166 \pm 19$ \\
Control mAb & $10 \mu \mathrm{g} / \mathrm{ml}$ & $203 \pm 20$ \\
EGF & $50 \mathrm{ng} / \mathrm{ml}$ & $932 \pm 84^{\S}$ \\
EGF plus VEGF mAb & $50 \mathrm{ng} / \mathrm{ml}$ and $10 \mu \mathrm{g} / \mathrm{ml}$ & $897 \pm 64^{\S}$ \\
EGF plus control mAb & $50 \mathrm{ng} / \mathrm{ml}$ and $10 \mu \mathrm{g} / \mathrm{ml}$ & $997 \pm 67^{\S}$ \\
& &
\end{tabular}

* After adherence of human colon carcinoma cells to beads and culture for $72 \mathrm{~h}$, a bead suspension was used to inoculate 24-well tissue culture plates containing either serum-free DMEM alone or the indicated growth factors or monoclonal antibodies. After an additional $48 \mathrm{~h}$, cells migrating off of the beads were enumerated as described in Methods.

${ }^{\ddagger}$ Mean \pm SEM of six replicate wells. ${ }^{8} P<0.001$ vs control by Student's $t$ test.

the random hexamer labeling method (Rediprime; Amersham Corp.). Typically, 1-2 $\times 10^{7} \mathrm{cpm}$ of ${ }^{32} \mathrm{P}$-labeled probe was used for an $80-\mathrm{cm}^{2}$ filter in $7 \mathrm{ml}$ of solution. Final washes were in $0.1 \times$ SSC, $0.1 \%$ SDS at $40^{\circ} \mathrm{C}$. The membranes were exposed to Kodak (Rochester, NY) XAR2 film with an intensifying screen at $-70^{\circ} \mathrm{C}$ for $24 \mathrm{~h}$. To control for total RNA content in each sample, the blots were stripped and subsequently rehybridized to a human glyceraldehyde phosphate dehydrogenase (GAPDH) probe (1.3-kb human GAPDH cDNA; American Type Culture Collection, Rockville, MD).

\section{Animal tumor growth}

Subcutaneous tumors. Confluent cultures of LS LiM6 or HM7 grown in $10 \mathrm{~cm}^{2}$ Petri dishes were harvested by brief trypsinization $(0.05 \%$ trypsin/0.02\% EDTA in $\mathrm{Ca}^{2+} / \mathrm{Mg}^{2+}$-free HBSS), washed several times in $\mathrm{Ca}^{2+} / \mathrm{Mg}^{2+}$-free PBS, and resuspended at a final concentration of 5 $\times 10^{7}$ cells $/ \mathrm{ml}$ in serum-free DMEM. The presence of single cells was confirmed by phase-contrast microscopy, and cell viability was determined by trypan blue exclusion. Pathogen-free Balb/c NCR-NU athymic mice (3-4-wk-old females obtained from Simonsen Laboratories, Gilroy, CA) were housed in sterilized cages and injected subcutaneously with $5 \times 10^{6}$ viable tumor cells. Animals were observed daily for tumor growth, and subcutaneous tumors were measured using a caliper every $3 \mathrm{~d}$. Beginning $1 \mathrm{~d}$ after tumor inoculation and every 3-4 d thereafter, animals were injected intraperitoneally with varying amounts of either anti-VEGF mAb 4.6.1 (0-200 $\mu \mathrm{g}$ per mouse) or a control mAb of the same isotype ( $200 \mu \mathrm{g} /$ mouse) (20) in a volume of $0.25 \mathrm{ml}$ in $0.9 \mathrm{M}$ $\mathrm{NaCl}$. Tumor volumes were calculated as previously described (29).

Liver metastases. HM7 cells were grown to confluence and harvested as described above for subcutaneous injection and resuspended in serumfree DMEM at a concentration of $20 \times 10^{6} \mathrm{cells} / \mathrm{ml}$. Athymic mice were anesthetized with methoxyfluorane by inhalation, prepared in a sterile fashion, and the spleen was exteriorized through a left flank incision. $2 \times 10^{6}$ cells in $100 \mu \mathrm{l}$ were slowly injected into the splenic pulp through a 27 -gauge needle over $1 \mathrm{~min}$, followed by splenectomy 1 min later. Experimental animals were given VEGF antibody 4.6.1 or control antibody (100 $\mu \mathrm{g} /$ mouse) by intraperitoneal injection beginning $1 \mathrm{~d}$ after splenic-portal injection and every 3-4 d thereafter. All animals were killed when the first mouse appeared lethargic and an enlarged liver could be palpated (day 28). The livers were excised and weighed, and the metastases were enumerated using a dissecting microscope. To estimate tumor volume, the diameter of each liver metastasis was measured to the nearest millimeter, and the volume of each tumor was calculated by assuming it to be a sphere. The sum of the volumes of all tumors in each liver was determined. The livers of two control animals were nearly replaced by tumor and individual nodules could not be distinguished. Tumor volume was estimated in these two livers as follows: the total liver volume was measured by displacement of water in a $20-\mathrm{ml}$ graduated cylinder, and the tumor volume was estimated to represent $85 \%$ of the liver (see Fig. 5).

\section{Statistics}

Mean values for tumor volumes, tumor weights, liver weights, and number of liver tumors and colon carcinoma cell migration were compared by the Student's $t$ test using a computer program (StatWorks) with $P<0.05$ considered significant.

\section{Results}

\section{VEGF gene expression in human liver metastases from} colorectal cancer

We first determined the relative abundance of VEGF transcripts in biopsied or resected hepatic metastases by Northern analysis using a cDNA probe which hybridizes with all known splice variants of VEGF mRNA. Tissue samples were taken from nonnecrotic areas of the tumor periphery and frozen immediately in liquid nitrogen. Hybridization of the VEGF probe to a major species of $3.3 \mathrm{~kb}$ with a lesser signal from a transcript of $4.4 \mathrm{~kb}$ is demonstrated in Fig. 1. Each of the 16 tumors analyzed expressed VEGF mRNA, but to varying degrees. This may reflect patient to patient variation in the ratio of stromal cells to neoplastic cells in the portion of tumor analyzed or a true variability in gene expression between different metastatic tumors. RNA was also extracted from adjacent grossly normal liver of those patients undergoing liver resection and subjected to Northern analysis for VEGF expression. A detectable signal for VEGF was observed in three out of five livers (data not shown). An additional 14 colorectal metastases were examined for VEGF gene expression by in situ hybridization using ${ }^{33} \mathrm{P}$ labeled antisense and sense riboprobes. Intense expression of VEGF was present in the majority of carcinoma cells in all 14 metastases, while labeling of tumor stromal cells did not exceed background levels seen with the sense VEGF riboprobe (Fig. $2, a$ and $b$ ). Specific hybridization of the VEGF antisense riboprobe to histologically normal liver was also demonstrated, although the level of VEGF gene expression was dramatically less than that seen in the tumors, consistent with the Northern analysis (Fig. 2, $e$ and $f$ ). VEGF message in the nontumorous liver was localized primarily to hepatocytes and scattered perisinusoidal cells in these sections. The same tumors were also analyzed for VEGF receptor gene expression by in situ hybridization using sense and antisense riboprobes for $f t-1$ and KDR. A majority of biopsies showed expression of both receptors localized to vascular endothelium within the connective tissue stroma of the carcinoma (Fig. 2, $c$ and $d$ ). None of the carcinoma cells within the tumor showed hybridization with probes for either receptor. flt-1 was more consistently expressed by tumor vessel endothelium (12/14 tumors) although a majority of biopsies showed concurrent fit and KDR expression (8/14). Control experiments using ${ }^{33} \mathrm{P}$-labeled sense riboprobes for KDR and flt1 produced very low levels of background labeling, comparable with that demonstrated for the VEGF sense riboprobe in Fig. $2, b$ and $f$ (data not shown). The lack of specific labeling of endothelial cells in both tumorous and histologically benign livers by the VEGF antisense riboprobe serves as a further control for the specific labeling of tumor vessel endothelium using the riboprobes for KDR and fit 1 . When adjacent normal 


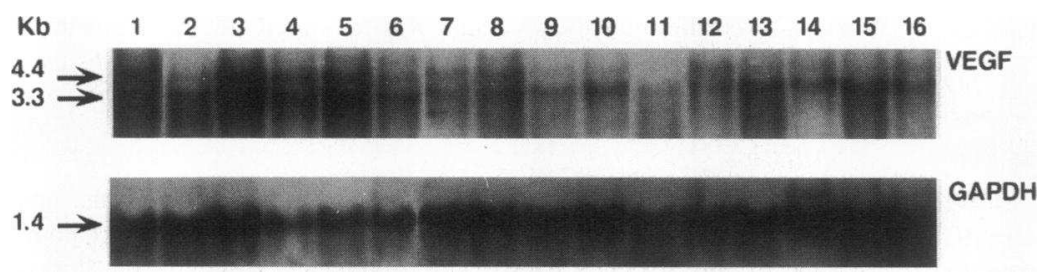

Figure 1. VEGF gene expression in human colorectal cancer liver metastases. Total RNA (20 $\mu \mathrm{g})$ extracted from 16 biopsied or resected liver metastases were separated by agarose gel electrophoresis, transferred to a nylon filter, and hybridized to a ${ }^{32} \mathrm{P}$-labeled cDNA probe for human VEGF $_{165}$ as described in Methods. Film exposure was for $24 \mathrm{~h}$. The predominant VEGF mRNA species expressed measured $\sim 3.3 \mathrm{~kb}$. The Northern blot was stripped and rehybridized using a probe for human GAPDH.

liver was examined by in situ hybridization, no expression of flt-1 or KDR could be demonstrated (data not shown).

\section{VEGF gene expression by human colon carcinoma cell} lines

We next examined several cultured human colon carcinoma lines for VEGF expression in vitro. All lines were grown to confluence in complete DMEM, cells were harvested, and total cellular RNA was extracted. By Northern analysis, eight out of eight cell lines constitutively expressed VEGF mRNA. A predominant transcript of $3.3 \mathrm{~kb}$ was identified (Fig. 3). While there was considerable variability in the absolute level of VEGF message among different cell lines, there was no clear relationship between the degree of cancer cell differentiation and steady state levels of VEGF mRNA. Three colon cancer lines, COLO 205, HCT 15, and LS LiM6, which exhibited low, intermediate, and strong signals for VEGF mRNA by Northern analysis, re- spectively (Fig. 3), were tested for secretion of VEGF immunoactivity. Cells were grown to confluence in $2.0 \mathrm{ml}$ of complete DMEM as described in Methods and changed to fresh DMEM. $48 \mathrm{~h}$ later, media from duplicate wells were collected and assayed for VEGF by ELISA. The concentrations of VEGF in media conditioned by COLO $205(0.65 \pm 0.01 \mathrm{ng} / \mathrm{ml}), \mathrm{HCT}$ $15(1.28 \pm 0.05 \mathrm{ng} / \mathrm{ml})$, and LS LiM6 $(2.19 \pm 0.32 \mathrm{ng} / \mathrm{ml})$ (mean \pm SEM) correlated well with the relative amount of VEGF mRNA in these cells determined by Northern analysis.

\section{Neutralization of VEGF in vivo}

Subcutaneous tumor growth. To determine the possible contribution of VEGF to tumor formation in vivo, we examined the growth of two human colon carcinoma lines HM7 and LS LiM6 in nude mice. Animals were given either a neutralizing monoclonal antibody to human VEGF or an isotypic control antibody by intraperitoneal injection twice weekly beginning $1 \mathrm{~d}$ after
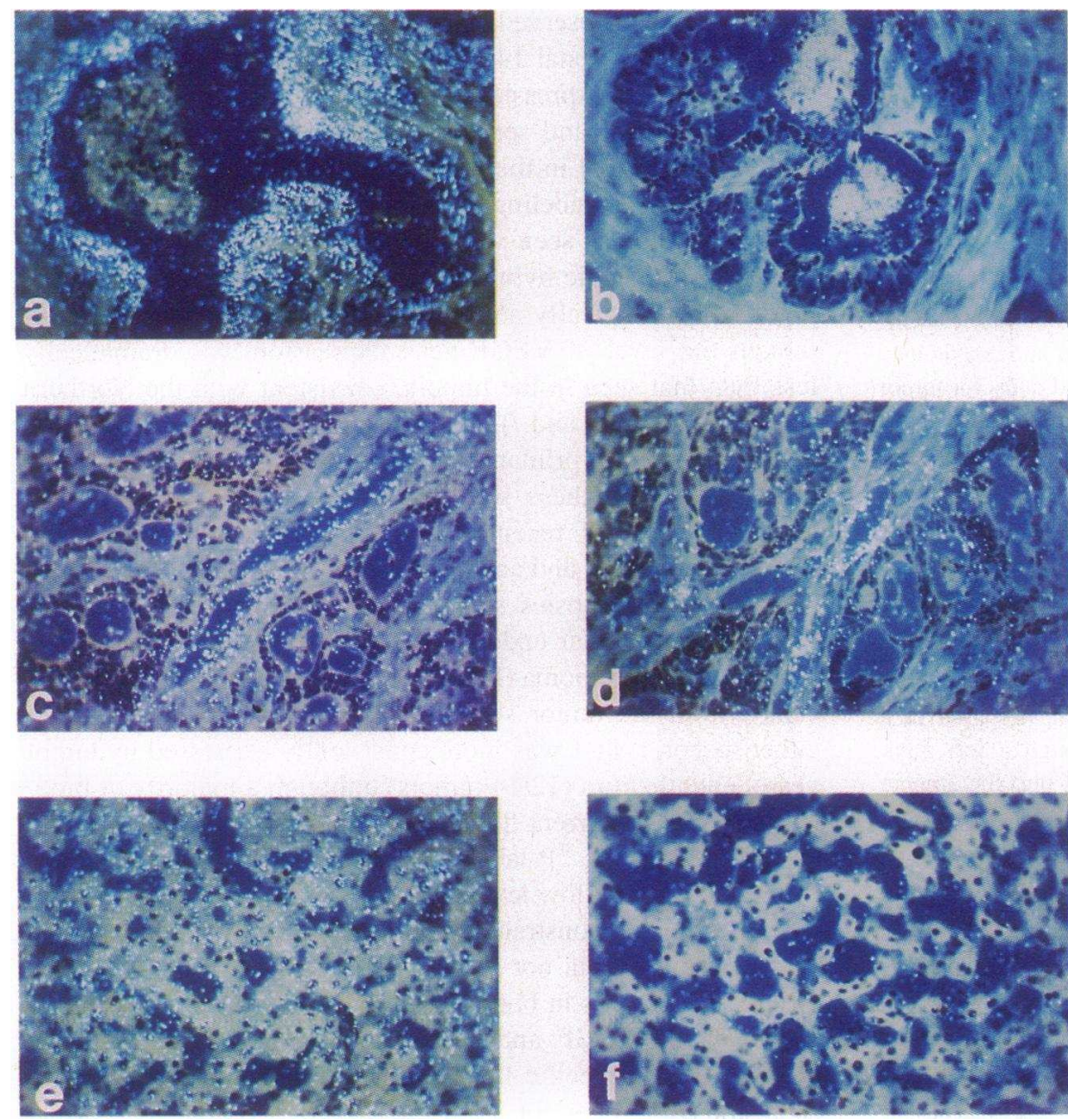

Figure 2. Photomicrographs of in situ hybridization of colon carcinoma metastases in the liver. (a) VEGF antisense probe. Note intense hybridization signal specific to the carcinoma cells. The signal is more intense toward the lumen of the tumor acini, presumably the areas of relative ischemia. (b) VEGF sense probe. Negative control. (c) KDR antisense probe. Note specific hybridization to the endothelium of the large vein; adjacent carcinoma cells are negative. (d) $f t$ antisense probe. Hybridization is confined to the endothelium of vessels; carcinoma cells are negative. ( $e$ ) Normal liver, VEGF antisense probe. Note specific hybridization centered predominantly on hepatocytes. The level of signal intensity is less than that noted for the carcinoma cells shown in $a$. $(f)$ Normal liver, VEGF sense probe. Negative control. 


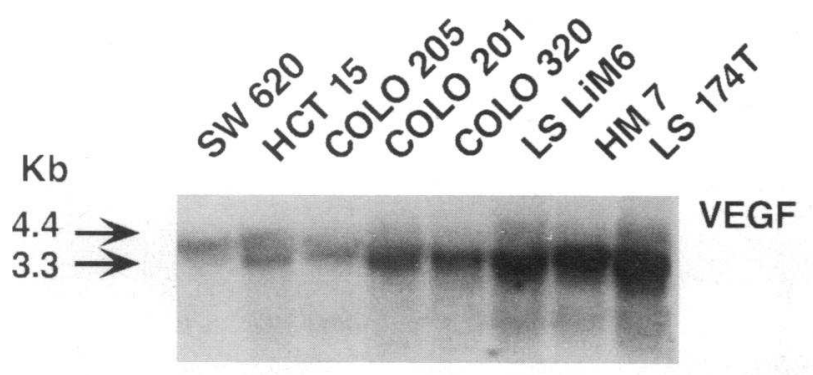

$1.4 \rightarrow$

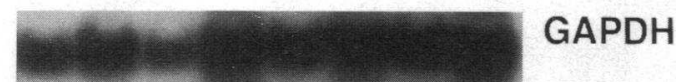

Figure 3. VEGF gene expression in eight human colorectal carcinoma cell lines. Cells were grown to confluence in complete DMEM medium containing $10 \%$ fetal bovine serum. RNA was extracted, and Northern analysis was performed using cDNA probes for human $\mathrm{VEGF}_{165}$ and GAPDH as in Fig. 1. Film exposure was $16 \mathrm{~h}$ for the VEGF hybridization.

subcutaneous inoculation of $5 \times 10^{6}$ cells into the flank. Animals were killed either $14 \mathrm{~d}$ (HM7) or $21 \mathrm{~d}$ (LS LiM6) later, and the subcutaneous tumors were carefully excised and weighed. While all animals developed tumors, anti-VEGF treatment led to a $76 \%$ reduction in tumor weight at day 14 (HM7) and an $88 \%$ reduction at day 21 (LS LiM6) (Fig. $4 A$ ). A separate group of 30 mice was then inoculated subcutaneously with LS LiM6 and treated twice weekly with either $0.9 \mathrm{M} \mathrm{NaCl}$, control mAb mp120 (200 $\mu \mathrm{g} /$ mouse), or with varying doses of anti-VEGF mAb 4.6.1, and tumor volumes were measured over 3 wk. A dose-dependent inhibition of tumor growth was observed over the range of mAb doses tested (10-200 $\mu \mathrm{g} / \mathrm{mouse})$ (Fig. 4 B). A $90 \%$ reduction in tumor volume was seen with a dose of $100 \mathrm{mg} / \mathrm{mouse}$ compared with the control mAb-treated animals. At the $10-\mu \mathrm{g}$ dose level, a significant reduction in tumor volume $(62 \%)$ was seen in comparison with the salinetreated controls $(P=0.033)$. Neither exogenous rhVEGF $(1-$ $50 \mathrm{ng} / \mathrm{ml})$ nor anti-VEGF mAb 4.6.1 $(10 \mu \mathrm{g} / \mathrm{ml})$ had any effect on proliferation of LS LiM 6 or HM7 cells in vitro (data not shown). We also examined the possibility that VEGF may act as an autocrine migration factor for colon carcinoma. LS LiM6 cells were cultured in the presence of microcarrier beads for 3 d. Beads to which cells had become adherent were then used to test the effect of either exogenous rhVEFF $_{165}$ or monoclonal antibody to VEGF in a 48-h migration assay (27) under serumfree conditions (Table I). Neutralizing antibody to human VEGF had no effect on either basal or epidermal growth factor-stimulated migration of LS LiM6 cells. Also, the addition of exogenous VEGF $(50 \mathrm{ng} / \mathrm{ml})$ similarly led to no stimulation of baseline cell migration in this assay. These data suggest that the inhibition of human colon cancer growth in the nude mouse by antibody 4.6.1 is not a consequence of an inhibition of cancer cell proliferation or motility.

Experimental hepatic metastases. The liver is typically the first and most frequent site of metastasis in colorectal cancer (30). Consequently, an effective antineoplastic therapy in this disease must be capable of modulating tumor growth at this orthotopic site. We chose to use a previously established model of experimental liver metastasis from human colorectal cancer in the athymic mouse to investigate the contribution of VEGF to hepatic tumorigenesis (25). The livers of 12 animals were
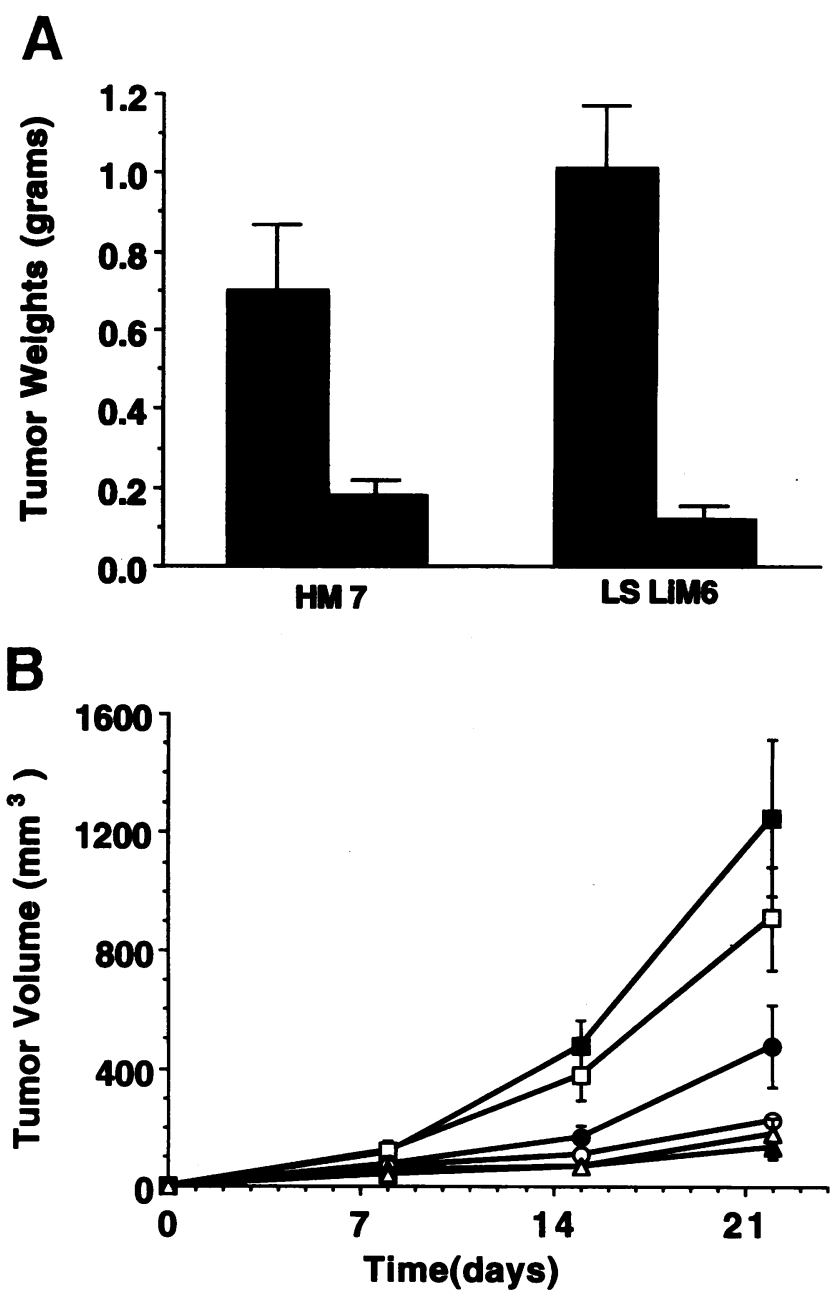

Figure 4. Neutralizing monoclonal antibody directed against human VEGF inhibits human colon cancer growth subcutaneously in the athymic mouse. (A) $1 \mathrm{~d}$ after subcutaneous inoculation of the human colon carcinoma cell lines LS LiM6 or HM7 into the flanks of athymic mice, intraperitoneal injection of either control mAb (solid bars) or antiVEGF mAb (gray bars) given twice weekly was begun. On either day 14 (HM7) or day 24 (LS LiM6) after inoculation, tumors were excised and weighed ( $n=5$ in each HM7 group and $n=10$ in each LS LiM6 group). (B) Dose-dependent inhibition of tumor growth by anti-VEGF $\mathrm{mAb}$. Groups of five athymic mice were inoculated subcutaneously with the colon carcinoma line LS LiM6, and $1 \mathrm{~d}$ later, intraperitoneal injections of either $0.9 \mathrm{M} \mathrm{NaCl}$ (filled boxes), control mAb (200 $\mu \mathrm{g}$, open boxes) or anti-VEGF mAb (10 $\mu \mathrm{g}$, filled circles; $50 \mu \mathrm{g}$, open triangles; $100 \mu \mathrm{g}$, open circles; or $200 \mu \mathrm{g}$, filled triangles) were begun and continued twice weekly for $3 \mathrm{wk}$. Tumor dimensions were measured with a caliper, and tumor volumes were calculated.

inoculated with HM7 cells by splenic-portal injection. This human colon carcinoma line has been shown to exhibit a high potential for spontaneous liver metastasis after cecal implantation (25). Beginning $1 \mathrm{~d}$ after inoculation, animals were treated by twice weekly intraperitoneal injections of either anti-VEGF or control monoclonal antibody $(100 \mu \mathrm{g} /$ dose $)$. All animals were killed $4 \mathrm{wk}$ later. The appearance of the livers of representative animals is given in Fig. 5. Again, all animals showed evidence of hepatic tumors, but a dramatic reduction in the number and size of liver metastases was observed in the anti-VEGF-treated animals. The average number of tumors per liver and the mean 


\section{VEGF mAb}

\section{Control mAb}

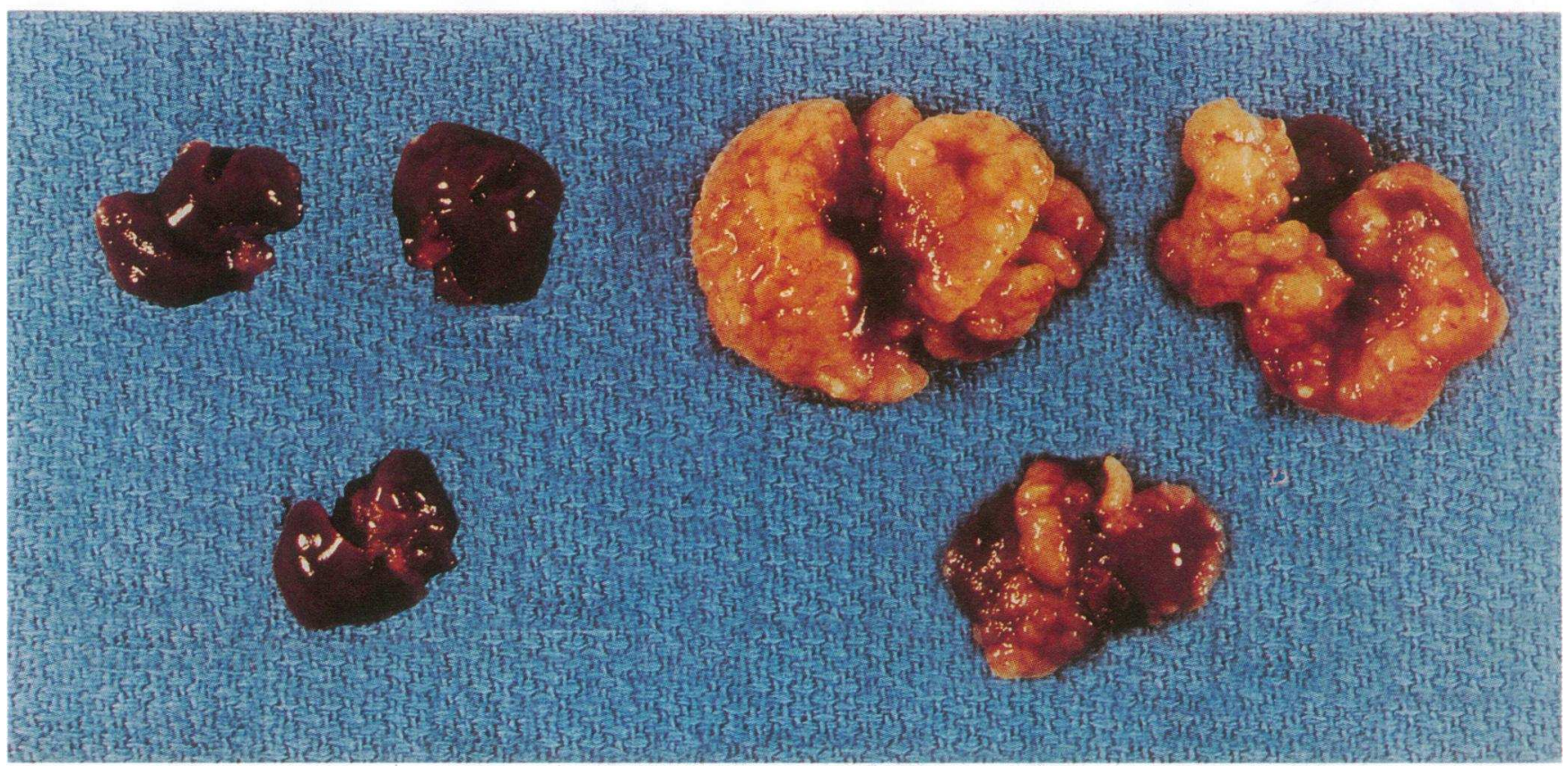

Figure 5. Neutralizing antibody to human VEGF inhibits growth of experimental hepatic metastases in the athymic mouse. $1 \mathrm{~d}$ after splenic-portal tumor cell inoculation ( 2 million HM7 cells), twice weekly antibody injections were begun, and animals were killed after 4 wk. Livers of representative animals are shown.

estimated tumor volume per liver were 10 - and 18 -fold greater, respectively, in the control animals versus the anti-VEGFtreated mice (Table II). Liver weights were also significantly greater in the control versus anti-VEGF-treated animals $(3.68 \pm 1.25 \mathrm{~g}$ vs $1.09 \pm 0.04 \mathrm{~g}$, respectively; $P=0.03)$. When the size distribution of liver tumors was examined, the influence of anti-VEGF therapy became even more evident. An average of $91 \%$ of tumors per liver in the anti-VEGF-treated mice was smaller than $1 \mathrm{~mm}$ and 6 out of 7 of these mice had no tumor

Table II. Effect of VEGF mAb Treatment of Athymic Mice Bearing Experimental Hepatic Metastases from Human Colorectal Carcinoma

\begin{tabular}{lccc}
\hline \multicolumn{1}{c}{ Parameter* } & $\begin{array}{c}\text { Anti-VEGF } \\
\text { mAb }\end{array}$ & Control mAb & $P^{\ddagger}$ \\
\hline $\begin{array}{l}\text { Number of tumors per liver } \\
\text { (range) }\end{array}$ & $22 \pm 9$ & $226 \pm 113$ & 0.05 \\
Tumor volume per liver $\left(\mathrm{mm}^{3}\right)$ & $166 \pm 183$ & $(13-500)$ & \\
Liver wt $(\mathrm{g})$ & $1.09 \pm 0.04$ & $3.68 \pm 1.25$ & 0.03 \\
Percentage of tumors $<1 \mathrm{~mm}$ & $91 \pm 5$ & $38 \pm 16$ & 0.005 \\
& & & \\
\hline
\end{tabular}

Athymic mice were given experimental hepatic metastases by splenic injection of 2 million human colon carcinoma cells (HM7). Beginning $1 \mathrm{~d}$ after tumor inoculation, mice were treated with either control ( $n$ $=5)$ or anti-VEGF $(n=7) \mathrm{mAb}(100 \mu \mathrm{g} /$ injection) by twice weekly intraperitoneal administration. $4 \mathrm{wk}$ after inoculation, all animals were killed, and various parameters of liver tumor growth were measured, as described in Methods. ${ }^{*}$ Mean \pm SEM. ${ }^{\ddagger} P$ value by Student's $t$ test.
$>3 \mathrm{~mm}$ in diameter. In contrast, only $\mathbf{3 8 \%}$ of the tumors from the control mice were under $1 \mathrm{~mm}$ in diameter, and all control animals were found to bear tumors measuring $8 \mathrm{~mm}$ or greater in diameter. Expression of VEGF and flk-1, the mouse homologue of the human VEGF receptor KDR, was analyzed in liver metastases of control $\mathrm{mAb}$ and anti-VEGF mAb-treated mice (Fig. 6). As we observed in biopsied human liver tumors, human colon cancer xenografts in the mouse liver strongly expressed VEGF mRNA. VEGF expression was confined to the epithelial cells within each tumor and was equivalent in the control and anti-VEGF-treated animals (Fig. 6, $a$ and $b$ ). Background labeling with a VEGF sense riboprobe in the experimental mouse liver metastases was comparable with that demonstrated with the sense riboprobe in the human liver metastases, as in Fig. 2 $b$ (data not shown). Strong labeling of tumor blood vessels was observed in the liver tumors of control antibody-treated mice, using the flk-1 antisense probe (Fig. 6 c). However, no blood vessels were identified in the small hepatic metastases of the anti-VEGF-treated mice, and we observed no specific hybridization of the flk-1 probe in these tumors (Fig. $6 d$ ).

\section{Discussion}

Approximately 60,000 patients die each year in the United States from colorectal cancer, and 40,000 of these will have liver metastases as the principal site of disease (31). It is estimated that liver resection for colorectal secondaries is curative in only $1,000-1,500$ of these individuals. Of the remaining patients, standard chemotherapeutic agents may be delivered either systemically or by regional infusion, but response rates 

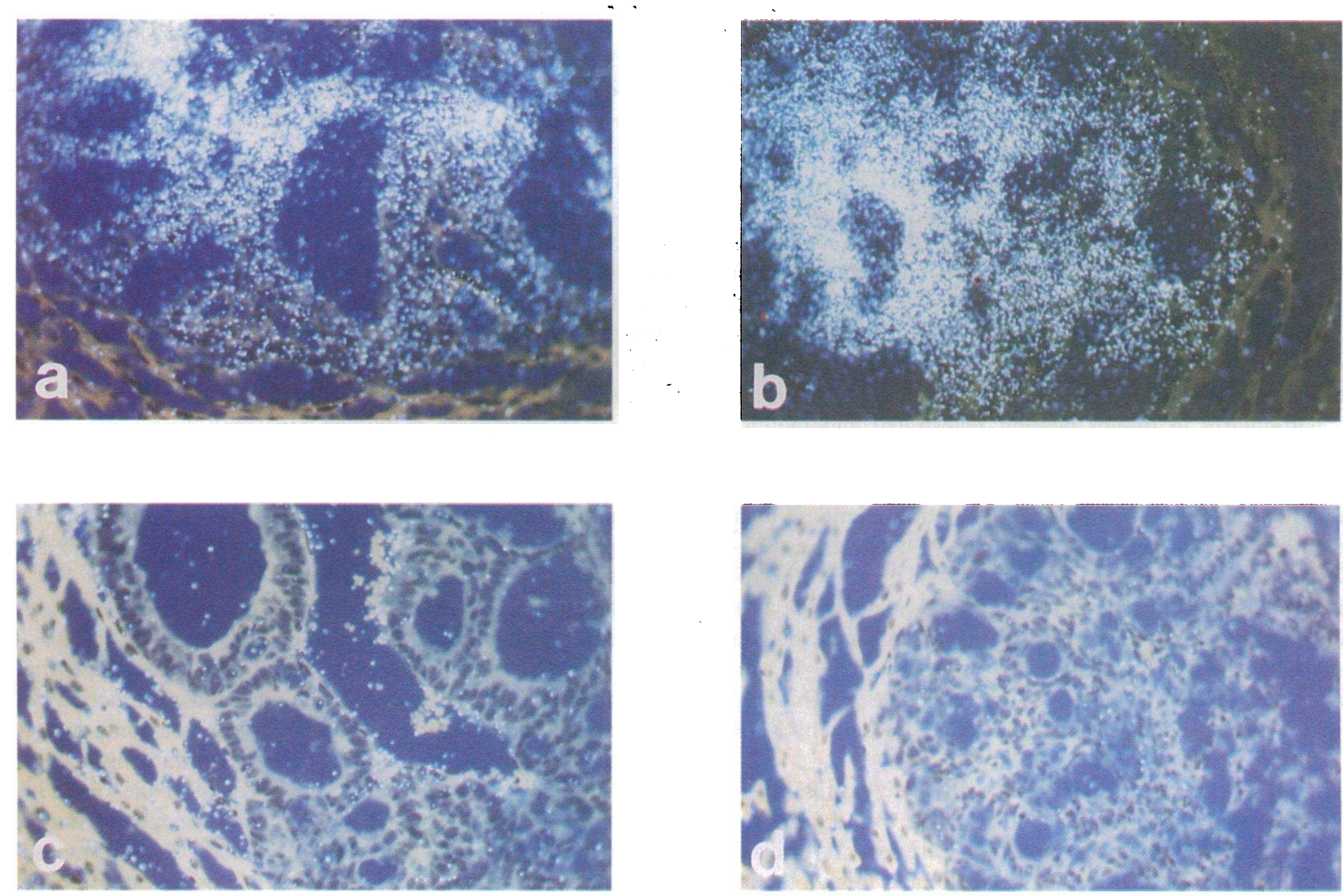

Figure 6. (a) Photomicrograph of in situ hybridization of VEGF antisense probe to section of carcinoma metastasis in the liver of a control nude mouse. Note intense hybridization to the carcinoma cells. (b) Photomicrograph of VEGF in situ hybridization to a carcinoma metastasis in the liver of a nude mouse treated with VEGF antibody. (c) Positive hybridization of Flk-1 antisense probe to the lining endothelium of a large blood vessel within a carcinoma metastasis in the liver of a control nude mouse. (d) In situ hybridization with a flk-1 antisense probe to a carcinoma metastasis in the liver of a nude mouse treated with VEGF antibody. Positive hybridization is present in rare perisinusoidal cells in the adjacent normal liver. Vessels are not present in the tumor metastasis from the anti-VEGF-treated mice, and probe hybridization is not evident.

do not exceed $50 \%$ and no patient is cured (32). In an effort to better understand the biology of metastasis in colorectal cancer, we have tested the hypothesis that angiogenesis plays a fundamental role in the formation of liver metastases from human colorectal cancer, and that the endothelial cell mitogen VEGF may act as a major regulator of hepatic tumorigenesis in this disease.

In agreement with this hypothesis, Northern analysis of cultured human colon carcinoma demonstrated expression of VEGF mRNA to varying degrees in all cell lines tested. The cDNA probe hybridized predominantly to a 3.3-kb mRNA species which probably represents VEGF $_{165}(5)$. Three of these lines were tested for VEGF secretion, and immunoreactive VEGF was identified in the conditioned media of these cells (COLO 205, HCT 15, and LS LiM6) in amounts which were proportional to their expression of VEGF mRNA. Several other peptide growth factors have been reported to act as direct endothelial mitogens, including basic fibroblast growth factor (bFGF), hepatocyte growth factor (HGF), and transforming growth factor alpha (TGF $\alpha$ ). bFGF has been well characterized as an angiogenic protein with a potency which is comparable with that of VEGF (33). The expression of bFGF in primary human colorectal cancers is sparse, however, and immunoactivity resides principally in the stromal cells of these tumors (34). While bFGF lacks a signal sequence and is not likely to act as a carcinoma-derived endothelial growth factor in human colorectal cancer, bFGF can be demonstrated in the extracellular matrix in many tissues and synergizes with VEGF using both in vitro and in vivo assays of angiogenesis (35). Consequently, a contributory role of bFGF in colon cancer metastasis formation cannot be excluded. HGF, also called scatter factor, can stimulate endothelial cell proliferation and migration in vitro and is angiogenic in a rabbit cornea assay (36). The HGF receptor, cMET, is overexpressed in colon cancers and may regulate the invasive behavior of these neoplasms (37). However, HGF, the cMET ligand, appears to be expressed by stromal cells rather than the carcinoma cells within human colon cancer metastases (our unpublished observations). While TGF $\alpha$ is secreted by a variety of human colon cancer lines, this growth factor and its receptor are expressed at comparable levels in benign and malignant gastrointestinal epithelium (38). Expression of other potential angiogenic factors in human colorectal cancer remains to be investigated.

That the expression of VEGF in colon carcinoma is not restricted to tumor cell lines in vitro is demonstrated by the finding of strong VEGF gene expression by either Northern analysis or in situ hybridization in each of 30 liver metastases from colon or rectal primaries. VEGF mRNA was identified throughout each tumor examined, but was confined to the malignant cells of the neoplasm. These data are consistent with the 
finding of Brown and co-workers (10) of an enhanced expression of VEGF in primary colon cancers compared with matched normal colonic mucosa. Adjacent, histologically normal liver in these patients also expressed VEGF mRNA, although at levels which were considerably lower than those found in the hepatic tumors. In agreement with the report of Monacci et al. (39) in the rat, in situ hybridization studies of normal human liver revealed that VEGF mRNA was localized to hepatocytes and to a small number of scattered Kupffer cells. The function of hepatocyte-derived VEGF is not clear. It has been suggested that in addition to a possible role in development and differentiation of the vascular system, VEGF may contribute to maintenance of vascular integrity and physiologic homeostasis in the adult, particularly in tissues bearing fenestrated endothelium such as the kidney, spleen, and liver (40). In addition to expression of the ligand, high affinity binding of ${ }^{125} \mathrm{I}$-VEGF to both small and large vessels in tissue sections of normal mouse liver has been reported (41). In the present study, however, no specific hybridization of RNA probes for either known VEGF receptor was observed in histologically normal human liver. It is possible that expression of either KDR or flt occurs in the human liver at levels which are too low to be detected by in situ hybridization. Alternatively, VEGF may associate with binding sites in hepatic endothelial cells which are not encoded by KDR or fit1.

In contrast with the surrounding normal liver, expression of both VEGF receptor genes was identified in the majority of hepatic metastases in which tumor vessels were seen. Hybridization of the probes for KDR and fit 1 was limited to endothelial cells of both large and small vessels in the neoplasms. Since it has been shown that after splenic tumor injection the vascular supply of experimental hepatic metastases develops from hepatic sinusoids (42), these data suggest that an up-regulation of KDR and fit 1 in sinusoidal endothelial cells occurs as a concomitant of hepatic tumorigenesis. The relative contribution of $\mathrm{KDR} / \mathrm{flk}-1$ and $\mathrm{flt} 1$ in mediating the various actions of vascular endothelial growth factor is unclear. Recent evidence suggests that KDR/flk-1 may be the more important site for transduction of the mitogenic activity of VEGF. Using porcine endothelial cells which lack endogenous VEGF receptors, Waltenberger and co-workers (43) demonstrated that cells transfected with KDR respond to VEGF by both proliferation and chemotaxis. However, cells expressing flt 1 lacked either of these responses (43). Consistent with these findings, Millauer et al. (19) showed that, by blocking functional flk-1 expression alone in rat glioblastoma in vivo using a dominant-negative flk1 mutant, tumor growth is dramatically diminished. It is possible that heterodimeric complexes between flk- 1 and fit 1 may exist which are inactivated by the dominant-negative flk-1 mutant lacking the intracellular kinase domain. However, the existence of such hybrid VEGF receptors has yet to be demonstrated.

The mechanism of the apparent increase in VEGF receptor mRNA expression in liver metastases is unknown, but may represent a key element in the regulation of colon cancer tumorigenesis in the liver. While the homologous up-regulation of other peptide hormone receptors by their cognate ligands has been reported $(44,45)$, preliminary experiments have failed to demonstrate an increase in binding of ${ }^{125}$ I-VEGF to bovine aortic endothelial cells exposed to $20 \mathrm{ng} / \mathrm{ml}$ of rhVEGF $_{165}$ for $24 \mathrm{~h}$. Heterogeneity is known to exist among endothelial cells derived from different tissues with regard to growth factor responsiveness (46), and bovine aortic endothelial cells may not accu- rately reflect the behavior of hepatic sinusoidal endothelium. Factors secreted by colon carcinoma cells other than VEGF may be responsible for heterologous up-regulation of KDR and flt1 in human liver metastases from colon cancer. Experiments are underway to test this hypothesis, using isolated rat liver sinusoidal endothelial cells exposed to either rhVEGF or to HM7 cell conditioned medium. Alternatively, the up-regulation of VEGF binding sites in tumor endothelial cells may occur under the influence of factors derived from other tumor stromal cells, such as fibroblasts, infiltrating leukocytes, or pericytes. Nevertheless, the recent finding of a similar up-regulation of VEGF receptor mRNA expression in tumor vessels relative to vessels in the surrounding normal parenchyma in a rat glioma model (47) as well as in human renal cell carcinomas (48) suggests that induction of KDR and flt 1 may represent a key element in the regulation of solid tumor formation. It will thus be important to better understand the mechanisms which govern the expression of KDR and $f t l$ in hepatic sinusoidal endothelium as a function of liver tumorigenesis.

While these data establish the presence of all elements of the VEGF system in metastatic colorectal cancer in humans, the in vivo studies provide evidence that this system is central to the formation and growth of hepatic secondary tumors. In a subcutaneous tumor model of human colon carcinoma in the nude mouse, intraperitoneal injection of neutralizing monoclonal antibody directed against VEGF delayed the onset of tumor formation and markedly diminished the rate of tumor growth in a dose- and time-related fashion. Using a mouse model of experimental liver metastases, the inhibitory effect of anti-VEGF treatment was even more pronounced. $4 \mathrm{wk}$ after intrasplenic tumor inoculation, all animals had developed liver tumors. However, the anti-VEGF-treated animals contained significantly fewer and significantly smaller tumors than the control group. Most of the tumors in the treated group were under $1 \mathrm{~mm}$ in diameter and all were under $3 \mathrm{~mm}$ in greatest dimension. This finding corresponds well to the estimation by Folkman (49) that tumors require neovascularization for growth beyond a diameter of 2-3 $\mathrm{mm}$.

The regimen of anti-VEGF administration in this investigation was begun $1 \mathrm{~d}$ after tumor inoculation and thus most closely resembles an adjuvant therapy. Future studies will examine the activity of a VEGF against established liver metastases in colorectal cancer. Targeting the tumor vasculature was first proposed by Folkman as a fundamentally novel approach to cancer treatment (49). Various agents which may inhibit tumor angiogenesis have been identified which act directly upon endothelial cells to block the proliferative response to mitogens (4). The present data emphasize, however, that despite the potential contribution of TGF $\alpha, \mathrm{HGF}$, and bFGF or other tumor-derived angiogenic growth factors, strategies designed to antagonize one specific endothelial mitogen, VEGF, may form the basis of an effective antineoplastic therapy in human colorectal cancer.

\section{Acknowledgments}

This work was supported in part by National Institutes of Health grant CA-52863 (R. S. Warren).

\section{References}

1. Kohn, E. C., and L. A. Loitta. 1993. Invasion and metastasis: new approaches to an old problem. Oncology (Basel). 7:47-52. 
2. Zetter, B. R. 1990. The cellular basis of site-specific tumor metastasis. $N$. Engl. J. Med. 322:605-612.

3. Folkman, J. 1992. The role of angiogenesis in tumor growth. Seminars in Cancer Biology. 3:65-71.

4. Folkman, J., and Y. Shing. 1992. Angiogenesis. J. Biol. Chem. 267:1093110934

5. Houch, K. A., N. Ferrara, J. Winer, G. Cachianes, and D. W. Leung. 1991. The vascular endothelial growth factor family: identification of a fourth molecular species and characterization of alternative splicing of RNA. Mol. Endocrinol. 5:1806-1814.

6. Ferrara, N., K. A. Houch, L. B. Jakeman, and D. W. Leung. 1992. Molecular and biological properties of the vascular endothelial growth factor family of proteins. Endocr. Rev. 13:18-32.

7. Park, J. E., G. A. Keller, and N. Ferrara. 1993. The vascular endothelial growth factor (VEGF) isoforms: differential deposition into the subepithelial extracellular matrix and bioactivity of extracellular matrix-bound VEGF. Mol. Cell. Biol. 4:1317-1326.

8. Senger, D. R., D. T. Connolly, L. Van de Water, J. Feder, and H. F. Dvorak. 1990. Purification and $\mathrm{NH}_{2}$-terminal amino acid sequence of guinea pig tumorsecreted vascular permeability factor. Cancer Res. 50:572-578.

9. Kondo, S., M. Asano, and H. Suzuki. 1993. Significance of vascular endothelial growth factor/vascular permeability factor for solid tumor growth and its inhibition by the antibody. Biochem. Biophys. Res. Commun. 194:1234-1241.

10. Brown, L. F., B. Berse, R. W. Jackman, K. Tognazzi, E. J. Manseau, D. R. Senger, and H. F. Dvorak. 1993. Expression of vascular permeability factor (vascular endothelial growth factor) and its receptors in adenocarcinomas of the gastrointestinal tract. Cancer Res. 53:4727-4735.

11. Olson, T. A., D. Mohanraj, L. F. Carson, and S. Ramakrishnan. 1994. Vascular permeability factor gene expression in normal and neoplastic human ovaries. Cancer Res. 54:276-280.

12. Plate, K. H., G. Breier, H. A. Weich, and W. Risau. 1992. Vascular endothelial growth factor is a potential tumor angiogenesis factor in human gliomas in vivo. Nature (Lond.). 359:845-848.

13. Kondo, S., M. Asano, K. Matsuo, I. Ohmori, and H. Suzuki. 1994. Vascular endothelial growth factor/vascular permeability factor is detectable in the sera of tumor-bearing mice and cancer patients. Biochem. Biophys. Acta. 1221:211-214.

14. Brown, L. F., B. Berse, R. W. Jackeman, K. Tognazzi, E. J. Manseau, H. F. Dvorak, and D. R. Senger. 1993. Increased expression of vascular permeability factor (vascular endothelial growth factor) and its receptors in kidney and bladder carcinomas. Cancer Res. 5:1255-1262.

15. Olander, J. V., D. T. Connolly, and J. E. DeLarco. 1991. Specific binding of vascular permeability factor to endothelial cells. Biochem. Biophys. Res. Commun. 175:68-76.

16. de Vries, C., J. A. Escobedo, H. Ueno, K. Houch, N. Ferrara, and L. T. Williams. 1992. The fms-like tyrosine kinase, a receptor for vascular endothelial growth factor. Science (Wash. DC). 255:989-991.

17. Terman, B. I., M. Dougher-Vermazen, M. E. Carrion, D. Dimitrov, D. C. Armellino, D. Gospodarowicz, and P. Bohlen. 1992. Identification of the KDR tyrosine kinase as a receptor for vascular endothelial cell growth factor. Biochem. Biophys. Res. Commun. 187:1579-1586.

18. Kim, J. K., J. Winer, M. Armanini, N. Gillett, H. S. Phillips, and N. Ferrara. 1993. Inhibition of vascular endothelial growth factor-induced angiogenesis suppresses tumor growth in vivo. Nature (Lond.). 362:841-844.

19. Millauer, B., L. K. Shawver, K. H. Plate, and A. Ullrich. 1993. High affinity VEGF binding and developmental expression suggest Flk-1 as a major regulator of vasculogenesis and angiogenesis. Cell. 72:835-846.

20. Ferrara, N., D. W. Leung, G. Cachianes, J. Winer, and W. J. Henzel. 1991. Purification and cloning of vascular endothelial growth factor secreted by folliculo-stellate cells. Methods Enzymol. 198:391-404.

21. Ferrara, N., J. Winer, T. Burton, A. Rowland, M. Siegel, and H. S. Phillips. 1993. Expression of vascular endothelial growth factor does not promote transformation but confers a growth advantage in vivo to chinese hamster ovary cells. J. Clin. Invest. 91:160-170.

22. Kim, J. K. B. Li, K. Houch, J. Winer, and N. Ferrara. 1992. The vascular endothelial growth factor proteins: identification of biologically relevant regions by neutralizing monoclonal antibodies. Growth Factors. 7:53-64.

23. Lu, L. H., and N. Gillett. 1994. An optimized protocol for in situ hybridization using PCR-generated ${ }^{33} \mathrm{P}$-labeled riboprobes. Cell Vision. 1:169-176.

24. Bresalier, R. S., S. E. Raper, E. S. Hujanen, and Y. S. Kim. 1987. A new animal model for human colon cancer metastasis. Int. J. Cancer 39:625-630.

25. Bresalier, R. S., Y. Niv, J. C. Byrd, Q.-Y. Duh, N. W. Toribara, R. W. Rockwell, R. Dahiya, and Y. S. Kim. 1991. Mucin production by human colonic carcinoma cells correlates with their metastatic potential in animal models of colon cancer metastasis. J. Clin. Invest. 87:1037-1045.

26. Sladowski, D., S. J. Steer, R. H. Clothier, and M. Balls. 1993. An improved MTT assay. Immunol. Methods. 157:203-207.

27. Rosen, E. M., L. Meromsky, E. Setter, D. W. Vinter, and I. D. Goldberg. 1990. Quantitation of cytokine-stimulated migration of endothelium and epithelium by a new assay using microcarrier beads. Exp. Cell Res. 186:22-31.

28. Chomczynski, P., and N. Sacchi. 1987. Single-step method of RNA isolation by acid guanidinium thiocyanate-phenol-chloroform extraction. Anal. Biochem. 162:156-159.

29. Kuan, S. F., J. C. Byrd, C. B. Basbaum, and Y. S. Kim. 1987. Characterization of quantitative mucin variants from a human colon cancer cell line. Cancer Res. 47:5715-5724.

30. Weiss, L., E. Grundmann, H. Torhorst, F. Hartveit, M. Moberg, and C. M. Fenoglio-Preiser. 1986. Haematogenous metastastic patterns in colonic carcinoma: an analysis of 1541 necropsies. J. Pathol. 150:195-203.

31. Levitan, N. 1993. Chemotherapy in colorectal carcinoma. Surg. Clin. North Am. 73:183-198.

32. Stagg, R. J., A. P. Venook, J. L. Chase, B. J. Lewis, R. S. Warren, M Roh, S. J. Mulvihill, B. J. Grobman, A. A. Rayner, and D. C. Hohn. 1991 Alternating hepatic intra-arterial floxuridine and fluorouracil: a less toxic regimen for treatment of liver metastases from colorectal cancer. J. Natl. Cancer Inst. 83:423-426.

33. Connolly, D. T. 1991. Vascular permeability factor: a unique regulator of blood vessel function. J. Cell. Biochem. 47:219-223.

34. Ohtani, H., S. Nakamura, Y. Watanabe, T. Mizoi, T. Saku, and H. Nagura. 1993. Immunocytochemical localization of basic fibroblast growth factor in carcinomas and inflammatory lesions of the human digestive tract. Lab Invest. 68:520527.

35. Goto, F., K. Goto, K. Weindel, and J. Folkman. 1993. Synergistic effects of vascular endothelial growth factor and basic fibroblast growth factor on the proliferation and cord formation of bovine capillary endothelial cells within collagen gels. Lab. Invest. 69:508-517.

36. Grant, D. S., H. K. Kleinman, I. D. Goldberg, M. M. Bhargava, B. J. Nickoloff, J. R. Kineslla, P. L. Polverini, and E. M. Rosen. 1993. Scatter facto induces blood vessel formation in vivo. Proc. Natl. Acad. Sci. USA. 90:19371941.

37. Di Renzo, M. F., R. P. Narshimhan, M. Olivero, S. Bretti, S. Giordano, E. Medico, P. Gaglia, P. Zara, and P. M. Comoglio. 1991. Expression of the Met/ HGF receptor in normal and neoplastic human tissues. Oncogene. 6:1997-2003.

38. Malden, L. T., U. Novak, and A. W. Burgess. 1989. Expression of transforming growth factor alpha messenger RNA in the normal and neoplastic gastrointestinal tract. Int. J. Cancer. 43:380-384.

39. Monacci, W. T., M. J. Merrill, and E. J. Oldfield. 1993. Expression of vascular permeability factor/vascular endothelial growth factor in normal rat tissues. Am. J. Physiol. 264:995-1002.

40. McGuire, R. F., D. M. Bissell, J. Boyes, and F. J. Roll. 1992. Role of extracellular matrix in regulating fenestrations of sinusoidal endothelial cells isolated from normal rat liver. Hepatology. 15:989-997.

41. Jackeman, L. B., J. Winer, G. L. Bennett, C. A. Altar, and N. Ferrara. 1992. Binding sites for vascular endothelial growth factor are localized on endothelial cells in adult rat tissues. J. Clin. Invest. 89:244-253.

42. Paku, S., and K. Lapis. 1993. Morphological aspects of angiogenesis in experimental liver metastases. Am. J. Pathol. 143:926-936.

43. Waltenberger, J., L. Claesson-Welsh, A. Siegbahn, M. Shibuya, and C. H. Heldin. 1994. Different signal transduction properties of KDR and Flt1, two receptors for vascular endothelial growth factor. J. Biol. Chem. 269:2698826995.

44. Sigegrist, W., S. Stutz, and A. N. Eberle. 1994. Homologous and heterologous regulation of $\alpha$-melanocyte stimulating hormone receptors in human and mouse melanoma cell lines. Cancer Res. 54:2604-2610.

45. Kell, P. A., J. Djiane, M. C. Postel-Vinay, and M. Edery. 1991. The prolactin/growth hormone receptor family. Endocr. Rev. 12:235-251.

46. Belloni, P. N., D. H. Carney, and G. L. Nicolson. 1992. Organ-derived microvessel endothelial cells exhibit differential responsiveness to thrombin and other growth factors. Microvasc. Res. 43:20-45.

47. Plate, K. H., G. Breier, B. Millauer, A. Ullrich, and W. Risau. 1993. Upregulation of vascular endothelial growth factor and its cognate receptors in a rat glioma model of tumor angiogenesis Cancer Res. 53:5822-5827.

48. Brown, L. F., B. Berse, R. W. Jackman, K. Tognazzi, E. J. Manseau, H. F. Dvorak, and D. R. Senger. 1993. Increased expression of vascular permeability factor (vascular endothelial growth factor) and its receptors in kidney and bladder carcinomas. Cancer Res. 5:1255-1262.

49. Folkman, J. 1971. Tumor angiogenesis: therapeutic implications. N. Engl. J. Med. 785:1182-1186. 